\title{
Correction to: Prevalence and mechanisms of antibiotic resistance in Escherichia coli isolated from mastitic dairy cattle in Canada
}

\author{
Satwik Majumder ${ }^{1}$, Dongyun Jung ${ }^{1}$, Jennifer Ronholm ${ }^{1,2^{*}}$ and Saji George ${ }^{1 *}$ \\ Correction to: BMC Microbiol 21, 222 (2021) \\ https://doi.org/10.1186/s12866-021-02280-5
}

Following the publication of the original article [1], we were notified that the following typos have been introduced during production:

In the Results section:

1. 'isolate 40,816,739 (with the slowest extrusion), and QC strain (with non-functional AcrAB-TolC)' should read 'isolate 40816739 (with the slowest extrusion), and QC strain (with non-functional AcrAB-TolC)'.

In the Discussions section:

1. 'The isolates $10,800,294$ and $21,914,232$ showed resistance to cefazolin and cefotaxime without ESBL' should read 'The isolates 10800294 and 21914232 showed resistance cefazolin and cefotaxime without ESBL'

2. 'Isolate 10,800,294 was a strong biofilm former and had an active AcrAB-TolC' should read 'Isolate 10800294 was a strong biofilm former and had an active AcrAB-TolC'.

The original article can be found online at https://doi.org/10.1186/s12866 021-02280-5.

* Correspondence: jennifer.ronholm@mcgill.ca; saji.george@mcgill.ca ${ }^{1}$ Department of Food Science and Agricultural Chemistry, McGill University, Macdonald Campus, 21111 Lakeshore Ste Anne de Bellevue, Quebec H9X 3V9, Canada

Full list of author information is available at the end of the article
In the Materials and Methods section:

1. 'E. coli ATCC 25,922, S. aureus ATCC 25,923, and P. aeruginosa ATCC 27,853 (Oxoid company, Canada)' should read 'E. coli ATCC 25922, S. aureus ATCC 25923, and P. aeruginosa ATCC 27853 (Oxoid company, Canada)'.

2. 'PPB without cell suspension was used as blank and E. coli ATCC 25,922 was used as a control' should read 'PPB without cell suspension was used as blank and E. coli ATCC 25922 was used as a control'.

3. 'E. coli ATCC 25,922 was used as a control strain to check the difference in biofilm formation' should read 'E. coli ATCC 25922 was used as a control strain to check the difference in biofilm formation'.

The original article has been corrected.

\begin{abstract}
Author details
${ }^{1}$ Department of Food Science and Agricultural Chemistry, McGill University, Macdonald Campus, 21111 Lakeshore Ste Anne de Bellevue, Quebec H9X 3V9, Canada. ${ }^{2}$ Department of Animal Science, McGill University, Macdonald Campus, 21111 Lakeshore Ste Anne de Bellevue, Quebec H9X 3V9, Canada.
\end{abstract}

Published online: 06 September 2021

\section{Reference}

1. Majumder, et al. Prevalence and mechanisms of antibiotic resistance in Escherichia coli isolated from mastitic dairy cattle in Canada. BMC Microbiol. 2021;21:222. https://doi.org/10.1186/s12866-021-02280-5.

(c) The Author(s). 2021 Open Access This article is licensed under a Creative Commons Attribution 4.0 International License, which permits use, sharing, adaptation, distribution and reproduction in any medium or format, as long as you give appropriate credit to the original author(s) and the source, provide a link to the Creative Commons licence, and indicate if changes were made. The images or other third party material in this article are included in the article's Creative Commons licence, unless indicated otherwise in a credit line to the material. If material is not included in the article's Creative Commons licence and your intended use is not permitted by statutory regulation or exceeds the permitted use, you will need to obtain permission directly from the copyright holder. To view a copy of this licence, visit http://creativecommons.org/licenses/by/4.0/. The Creative Commons Public Domain Dedication waiver (http://creativecommons.org/publicdomain/zero/1.0/) applies to the data made available in this article, unless otherwise stated in a credit line to the data. 